\title{
p53 Codon 72 Polymorphism and Risk of Cervical Cancer
}

\author{
JOSÉ M OJEDA ${ }^{1}$, SANDRA AMPUERO $^{1}$, PATRICIO ROJAS $^{2}$, RODRIGO PRADO $^{1}$, \\ JORGE E ALLENDE ${ }^{2}$, SARA A BARTON ${ }^{3}$, RANAJIT CHAKRABORTY ${ }^{4}$ and \\ FRANCISCO ROTHHAMMER ${ }^{5}$.
}

\begin{abstract}
${ }^{1}$ Centro de Oncología Preventiva, ${ }^{2}$ Programa de Biología Celular y Molecular, ICBM, Facultad de Medicina, Universidad de Chile. Santiago. ${ }^{3}$ Human Genetics Center, School of Public Health, The University of Texas, PO BOX 20186, Houston, Texas 77225. ${ }^{4}$ Center for Genome Information, Department of Environmental Health, University of Cincinnati, Cincinnati, Ohio 45267 and ${ }^{5}$ Programa de Genética Humana, ICBM, Facultad de Medicina, Universidad de Chile, Santiago.
\end{abstract}

\begin{abstract}
Storey et al. (1998) implicated the proline/argine polymorphism of the codon 72 of the tumor-suppressor gene p53 in the development of cervical cancer (CC) with the observation that the p53 protein is more efficiently inactivated by the E6 oncoprotein of human papillomavirus in p53 arginine as compared with its proline isoform. These authors further noted that in the United Kingdom, individuals homozygous for the arginine allele were several times more susceptible to HPV-associated tumorigenesis that proline/arginine heterozygotes. Subsequent studies in different countries failed to unanimously confirm this association. Motivated by the high incidence of $\mathrm{CC}$ in Chile, we undertook a case control study obtaining the following frequencies for genotypes PP, AP and AA in 60 ICC cases and 53 carefully selected controls: 0.067, 0.250, 0.683 and $0.075,0.453,0.472$ respectively. A significant difference $\left(X^{2}=3.19 \mathrm{p}<0.02\right)$ and an odds ratio of 2.62 supported Storey et al (1998)'s results. In addition, rejecting previous hypotheses about the world distribution of the p53 codon 72 polymorphism, we conclude that this distribution most likely represents ancient human dispersal routes. Several methodological and biological explanations for the results obtained in previous negative association studies are briefly discussed.
\end{abstract}

\section{INTRODUCTION}

Cervical cancer (CC) together with other anogenital tract cancers account for almost $12 \%$ of all carcinomas in women, representing the second most frequent group of gynecological malignancies in the world (Ferlay et al. 2001). Epidemiological and virological studies have shown that high risk human papillomavirus (HPV) infections (particularly those caused by genotypes 16 and 18) are one of the most important factors identified and probably the main cause for cervical cancer (Muñoz et al. 2000; zur Hausen 2002). However the fact that not all women infected with these viruses develop cancer indicates that HPV is not a sufficient cause for the malignant transformation.
In fact, the proline/argine polymorphism of the codon 72 of the tumor-suppressor gene p53 has been implicated in the development of cervical cancer (CC) in a study by Storey et al. (1998) with the observation that the p53 protein is more efficiently inactivated by the E6 oncoprotein of human papillomavirus in p53 arginine as compared with its proline isoform. Consequently, these authors noted that, in the United Kingdom, individuals homozygous for the arginine allele were about seven times more susceptible to HPV-associated tumorigenesis than proline/ arginine heterozygotes. Subsequent studies in several countries (Rosenthal et al., 1998; Lanham et al., 1998; Minaguchi et al., 1998; Hayes et al., 1998; Helland et al., 1998; Josefsson et al., 1998; Hildesheim et 
al., 1998; Ngan et al., 1999; Tachezy et al., 1999; Dybikowska et al., 2000; Klug et al., 2001; Suárez-Rincon et al., 2002) failed to confirm this association, leading to the suspicion that in the process of HPVassociated tumorigenesis due to genotype differences at the codon 72 of p53, other factors in addition to these isoforms of p53 are important as risk factors for the development of cervical cancer.

Motivated by the recent publication of three studies (Andersson et al., 2001; Pegoraro et al., 2002; Saranath et al., 2002) that confirmed original Storey et al. (1998) results, as well as by the fact that cervical cancer has a high incidence in Chile, and finally by the idea that the investigation of the differential effects of the p53 polymorphism in different populations could further contribute to unraveling the complexities of its function, we undertook a case control study of the p53 polymorphism and cervical carcinoma in the population of Santiago. To our knowledge, there is no data on this subject in the Chilean population.

\section{SUBJECTS AND METHODS}

The Chilean mixed population of Santiago has an average Amerindian admixture of 40\% (Rothhammer, 1987). Amerindian admixture and socioeconomic level are associated in Chile, a complication that must be taken into account in case control studies in order to avoid spurious results due to population stratification. Sixty patients belonging to the Chilean mixed populations, the same age group, and socioeconomic level with newly-diagnosed and histologically-confirmed invasive cervical cancer were identified by the Centro de Oncología Preventiva. Fifty-three matched controls were recruited from women without cervical cancer or diseases associated with known risk factors for this malignancy. An informed consent was obtained from all subjects.

Cervical cells and blood samples were collected from cases and controls. Cervical specimens were processed for Papanicolaou stain and cytological diagnosis. DNA was extracted from peripheral leukocytes. First, white blood cells were separated from red blood cells by incubation in lysis buffer, resuspended in TNE buffer containing $0.5 \%$ SDS and $250 \mathrm{ug} / \mathrm{L}$ prteinaseK (Boehringer Mannheim) and incubated at $37^{\circ} \mathrm{C}$ overnight. Protein was precipitated with $\mathrm{NaCl}$ and DNA extracted with phenol/ chloroform and precipitated with cold ethanol. All DNA samples were dissolved in water and stored at $-20{ }^{\circ} \mathrm{C}$. The quality of DNA was monitored by OD 260/280 measures.

Genotyping of p53 at codon 72 was carried out with an allele specific PCR amplification procedure. Two pairs of primers with different $3^{\prime}$ terminal bases were used to amplify p53 sequences separately: p53-p1 (GC-CAGAGGCTGCTCCCC) and p53-p2 (CGTGCAAGTCA-CAGACTT) for proline (178 base pairs [bp]) and p53-a1 (TCCCCCTTGCCGTCCCAA) and p53-a2 (CTGGTG-CAGGGGCCACG) for arginine (142 bp). The p53 arginine and proline variants were separately amplified from each sample with primers as described by Storey et al. (1998). The PCR reaction was performed in a total volume of $25 \mathrm{uL}$. The PCR mixture contained $10 \mathrm{mM}$ Tris-Cl, $\mathrm{pH} 8.3 ; 50 \mathrm{mM}$ $\mathrm{KCl} ; 1.5 \mathrm{mM} \mathrm{MgCl} ; 0.01 \%$ gelatin; $200 \mathrm{pmol}$ of each primer; $0.5 \mathrm{U}$ Taq DNA polymerase; and $100 \mathrm{ng}$ DNA. Amplification was performed with denaturation at $95{ }^{\circ} \mathrm{C}$ for 5 minutes followed by 30 cycles of 1 minute at $95^{\circ} \mathrm{C}, 1.5$ minutes at $72{ }^{\circ} \mathrm{C}$, and a final extension for 15 minutes at $72{ }^{\circ} \mathrm{C}$. The resulting PCR products of each sample were then mixed electrophoresed on $2 \%$ agarose gels and visualized under UV with ethidium bromide staining.

\section{RESULTS}

DNA amplification using the specific set of primers showed that DNA from all specimens was suitable for PCR analysis. p53 homozygotes for Arg and p53 homozygotes for Pro were observed as specific bands with expected sizes of $141 \mathrm{bp}$ and $177 \mathrm{bp}$ repectively.

The distribution of p53 codon 72 genotypes in healthy women were as follows: 4 samples were proline 
homozygotes (Pro/Pro 7.5\%), 25 arginine homozygotes (Arg/Arg 47.2\%), and 24 heterozygotes (Arg/Pro 45.3\%. Among the 60 cervical cancer patients, 4 were Pro/Pro (6.7\%), 41 Arg/Arg (68.3\%), and 15 were Arg/Pro (25\%).

A statistically significant odds ratio of 2.62 was obtained in our study. Consequently, homozigote women for arginine in Santiago have a 2.6-fold increased risk for cervical cancer.

p53 genotype and allele frequencies, in cancer patient samples from different countries are exhibited as Table I. Significant differences between cases and controls were observed in the UK $\left(\mathrm{X}^{2}=11.19 \mathrm{p}<0.001\right)$ (Storey et al., 1998), in Sweden $\left(\mathrm{X}^{2}=1680\right.$ $\mathrm{p}<0.0001)$ (Andersson et al. (2001), in South Africa $\left(\mathrm{X}^{2}=57.99 \mathrm{p}<0.0001\right)$ (Pegoraro et al., 2002), in India $\left(\mathrm{X}^{2}=6.34 \mathrm{p}<0.01\right)$ (Saranath et al., 2002), and as already mentioned, in Chile $\left(\mathrm{X}^{2}=5.19 \mathrm{p}<0.02\right)$.

The combined results of all studies reveal however that gene frequencies for the A1 (Pro) and A2 (Arg) alleles, as well as genotype frequencies do not differ significantly for cases and controls, leading to a non-significant Mantel-Haenzel odds ratio of 1.10 (95\% CI 0.51-2.72).

\section{DISCUSSION}

Methodological shortcomings such as the lack of representativeness or genetic heterogeneity of some samples, improper selection of control groups, and technical problems related to genotyping may be partially responsible for some inconclusive results observed in the reviewed studies (Table I). It is worth noting that populations exhibiting lower A2 (Arg) frequencies for numerical reasons manifest on the average higher odds ratios, $(\mathrm{r}=-0.52 \mathrm{p}<0.01)$. Similarly, a significantly lower mean arginine homozygote frequency $(0.235)$ was found in populations in which significant associations between the p53 codon 72 polymorphims and cervical cancer were detected, with respect to populations in which these associations were not found to be significant (0.522). Therefore some negative results may be a consequence of high A2 (Arg) frequencies in control populations and not necessarily a lack of association.

Beckman et al. (1994) claimed that the frequency of the A1 (Pro) allele showed a north-south cline and that there was a significant correlation between A2 (Arg)

TABLE I

p53 polymorphism phenotypic and allele frequencies in cervical cancer patients

\begin{tabular}{|c|c|c|c|c|c|c|c|}
\hline Country & $\mathrm{N}$ & $\mathrm{A}_{1}(\mathrm{P})$ & $A_{2}(A)$ & PP & $\mathrm{AP}$ & $\mathrm{AA}$ & Author \\
\hline Norway & 77 & 0.279 & 0.721 & 0.130 & 0.300 & 0.570 & Helland et al., 1998 \\
\hline Sweden & 488 & 0.280 & 0.720 & 0.080 & 0.390 & 0.520 & Josefsson et al., 1998 \\
\hline Sweden & 111 & 0.145 & 0.855 & 0.000 & 0.290 & 0.710 & Andersson et al., 2001 \\
\hline UK & 50 & 0.260 & 0.740 & 0.060 & 0.400 & 0.540 & Rosenthal et al., 1998 \\
\hline UK & 38 & 0.276 & 0.724 & 0.079 & 0.395 & 0.526 & Lanham et al., 1998 \\
\hline UK & 30 & 0.150 & 0.850 & 0.066 & 0.166 & 0.766 & Storey et al., 1998 \\
\hline Holland & 25 & 0.180 & 0.820 & 0.040 & 0.280 & 0.680 & Hayes et al., 1998 \\
\hline Poland & 44 & 0.160 & 0.840 & 0.023 & 0.273 & 0.704 & Dybikowska et al., 2000 \\
\hline Czech Republic & 71 & 0.282 & 0.718 & 0.085 & 0.394 & 0.521 & Tachezy et al., 1999 \\
\hline Japan & 103 & 0.354 & 0.646 & 0.100 & 0.500 & 0.400 & Minaguchi et al., 1998 \\
\hline China & 102 & 0.451 & 0.549 & 0.206 & 0.490 & 0.304 & Ngan et al., 1999 \\
\hline India & 134 & 0.460 & 0.540 & 0.180 & 0.560 & 0.260 & Saranath et al., 2002 \\
\hline South Africa & 281 & 0.417 & 0.583 & 0.174 & 0.660 & 0.340 & Pegoraro et al., 2002 \\
\hline USA & 187 & 0.321 & 0.679 & 0.097 & 0.449 & 0.454 & Hildesheim et al., 1998 \\
\hline Costa Rica & 49 & 0.367 & 0.633 & 0.143 & 0.449 & 0.408 & Hildesheim et al., 1998 \\
\hline Perú & 119 & 0.310 & 0.690 & 0.118 & 0.378 & 0.504 & Klug et al., 2001 \\
\hline Chile & 60 & 0.192 & 0.808 & 0.067 & 0.250 & 0.683 & This study \\
\hline
\end{tabular}


and latitude. Moreover, they suggested that the codon-72 polymorphism was balanced and maintained by natural selection. Using Beckman et al., (1994) data and the information that has become available since the publication of their report (Table II) we computed the correlation between the A2 (Arg) frequencies and latitude and obtained $\mathrm{r}=0.59(\mathrm{p}<0.01)$, confirming the Beckman et al. (1994) results. Nevertheless, if the genotypes in agglomerated control populations $(\mathrm{N}=3155)$ are tested for Hardy-Weinberg proportions, no significant deviations are found, detracting from the argument that the p53 codon 72 polymorphism is balanced.

Furthermore, although the p53 codon 72 polymorphism has been associated with an increased susceptibility to malignant conversion for various neoplastic diseases including lung cancer, (Wang et al., 1999), hepatocellular carcinoma, (Yu et al., 1999), ovarian and endometrical cancer, (Peller et al., 1999), urologic cancer, (Wu et al., 1995) and upper aero-digestive tract cancer, it is unlikely that these associations play a role in the maintenance of the polymorphism, since the onset of most cancers occurs after reproduction. The hypothesis of Beckman et al. (1994) that the world distribution of codon 72 polymorphism reflect an adaptation to ultra violet radiation is contradicted by the high A2 (Arg) frequencies found in Central and South America. We suggest that the world distribution of the p53 codon 72 polymorphism reflects ancient human migration routes, more specifically the dispersal of modern Homo sapiens out of Africa some 100,000-150,000 years ago.

With respect to the relationship between p53 genotypes and cervical carcinoma, the association is undoubtedly more complex than initially postulated and warrants additional studies in patients with more clearly defined tumor types (e.g., squamous cell versus adenocarcinoma), differences with respect to invasiveness of the cancer and the presence of different strains of HPVs. Studies in ethnic populations with different genetic backgrounds but similar ecogeographic areas may provide interesting new insights on this polymorphism in the future.

TABLE II

p53 polymorphism in different populations

\begin{tabular}{|c|c|c|c|c|c|c|c|}
\hline Country & $\mathrm{N}$ & $\mathrm{A}_{1}(\mathrm{P})$ & $\mathrm{A}_{2}(\mathrm{~A})$ & $\mathrm{PP}$ & $\mathrm{AP}$ & AA & Author \\
\hline Finland & 171 & 0.243 & 0.757 & 0.053 & 0.380 & 0.567 & Beckman et al., 1994 \\
\hline Norway & 225 & 0.258 & 0.742 & 0.060 & 0.400 & 0.540 & Helland et al., 1998 \\
\hline Sweden & 626 & 0.307 & 0.693 & 0.111 & 0.390 & 0.500 & Josefsson et al., 1998 \\
\hline Sweden & 188 & 0.310 & 0.690 & 0.090 & 0.440 & 0.470 & Andersson et al., 2001 \\
\hline UK & 246 & 0.222 & 0.778 & 0.069 & 0.305 & 0.626 & Rosenthal et al., 1998 \\
\hline UK & 250 & 0.246 & 0.754 & 0.060 & 0.372 & 0.568 & Lanham et al., 1998 \\
\hline UK & 41 & 0.342 & 0.658 & 0.049 & 0.585 & 0.366 & Storey et al., 1998 \\
\hline Holland & 158 & 0.240 & 0.759 & 0.060 & 0.370 & 0.570 & Hayes et al., 1998 \\
\hline Poland & 52 & 0.153 & 0.847 & 0.038 & 0.231 & 0.731 & Dybikowska et al., 2000 \\
\hline Czech Republic & 172 & 0.288 & 0.712 & 0.110 & 0.355 & 0.535 & Tachezy et al., 1999 \\
\hline Spain & 90 & 0.320 & 0.680 & 0.102 & 0.435 & 0.463 & Beckman et al., 1994 \\
\hline Japan & 110 & 0.404 & 0.595 & 0.180 & 0.460 & 0.360 & Minaguchi et al.,1998 \\
\hline China & 68 & 0.449 & 0.551 & 0.120 & 0.660 & 0.220 & Ngan et al., 1999 \\
\hline India & 131 & 0.505 & 0.495 & 0.150 & 0.710 & 0.140 & Saranath et al., 2002 \\
\hline India & 71 & 0.542 & 0.458 & 0.296 & 0.493 & 0.211 & Beckman et al., 1994 \\
\hline Nigeria & 122 & 0.631 & 0.369 & 0.385 & 0.492 & 0.123 & Beckman et al., 1994 \\
\hline South Africa & 340 & 0.690 & 0.310 & 0.470 & 0.440 & 0.090 & Pegoraro et al., 2002 \\
\hline USA & 245 & 0.282 & 0.718 & 0.082 & 0.400 & 0.518 & Hildesheim et al., 1998 \\
\hline Costa Rica & 123 & 0.309 & 0.691 & 0.065 & 0.488 & 0.447 & Hildesheim et al., 1998 \\
\hline Perú & 127 & 0.303 & 0.697 & 0.126 & 0.354 & 0.520 & Klug et al., 2001 \\
\hline Chile & 53 & 0.302 & 0.698 & 0.075 & 0.453 & 0.472 & This study \\
\hline Chilean Amerinds & 25 & 0.240 & 0.760 & 0.080 & 0.320 & 0.600 & This study \\
\hline
\end{tabular}




\section{ACKNOWLEDGMENTS}

This work was partially supported by the CBB Milennium Institute (FR), ICGEB (JEA) and Corporación Nacional del Cáncer (JMO) grants.

\section{REFERENCES}

ANDERSSON S, RYLANDER E, STRAND A, SALLSTROM J, WILANDER E (2001) The significance of p53 codon 72 polymorphism for the development of cervical adenocarcinomas. Br J Cancer 85(8): 1153-1156

BECKMAN G, BIRGANDER R, SJALANDER A, SAHA N, HOLMBERG PA, KIVELA A, BECKMAN L (1994) Is p53 polymorphism maintained by natural selection? Hum Hered 44: 266-270

DYBIKOWSKA A, DETTLAFF A, KONOPA K, PODHAJSKA A (2000) p53 codon 72 polymorphism in cervical cancer patients and healthy women from Poland. Acta Biochim Pol 47(4): 1179-1182

FERLAY J, BRAY F, PISANI P, PARKIN DM, (2001) GLOCOCAN 2000. Cancer incidence, mortality and prevalence worldwide, version 1.0. IARC Cancer Base $\mathrm{N}^{\circ}$ 5. Lyons, France: IARC Press

HAYES VM, HOFSTRA RMW, BUYS CHCM, HOLLEMA H, VANDER ZEE AGY (1998) Homozygous arginine - 72 in wild type p53 and risk of cervical cancer. Lancet 352: 1756

HELLAND A, LANGEROD A, JOHNSEN H, OLSEN AO, SKOVLUND E, BORRESEN-DALE AL (1998) p53 polymorphism and risk of cervical cancer. Nature 396: 530-531

HILDESHEIM A, SCHIFFMAN M, BRINTON LA, FRAUMENI YF, HERRERO R, BRATTI MC, SCHWARTZ P MORTEL R, BARNES W, GREENBERG M, MCGOWAN L, SCOTT D, MARTIN M, HERRERA U, CARRINGTON M (1998) p53 polymorphism and risk of cervical cancer. Nature 396: 532

JOSEFSSON AM, MAGNUSSON PKE, YLITALO N, QUARFORTH-TUBBEIR P, PONTEN Y, ADAMI HO, GYLLENSTEN UB (1998) p53 polymorphism and risk of cervical cancer Nature 396: 531, discussion 532

KLUG SJ, WILMOTTE R, SANTOS C, ALMONTE M, HERRERO R, GUERRERO I, CÁCERES E, PEIXOTO-GUIMARAES D, LENOIR G, HAINAUT P, WALBOOMERS JM, MUNOZ N (2001) TP53 polymorphism, HPV infection, and risk of cervical cancer. Cancer Epidemiol Biomarkers Prev 10(9): 1009-1012

LANHAM S, CAMPBELL I, WATT P, GORNALL R (1998) p53 polymorphism and risk of cervical cancer. Lancet 352: 1631

MINAGUCHI T, KANAMORI Y, MATSUHIMA M, YOSHIKAWA H, TAKETANI Y, NAKAMURA Y (1998) No evidence of correlation between polymorphism at Codon 72 of p53 and risk of cervical cancer in Japanese patients with human papillomavirus 16/18 infection. Cancer Res 58: 4585-4586
MUÑOZ N (2000) Human papillomavirus and cancer: the epidemiological evidence. J Clin Virol 19: 1-5

NGAN HYS, LIU VWS, LIU SS (1999) Risk of cervical cancer is not increased in Chinese carrying homozygous arginine at codon 72 of p53. Brit J Cancer 80: $1828-1829$

PEGORARO RJ, ROM L, LANNING PA, MOODLEY M, NAIKER S, MOODLEY J (2002) P53 codon 72 polymorphism and human papillomavirus type in relation to cervical cancer in South African women. Int J Gynecol Cancer 12(4): 383-388

PELLER S, HALPERIN R, SCHNEIDER D, KOPILOVA Y, ROTTER V (1999) Polymorphisms of the p53 gene in women with ovarian or endometrial carcinoma. Oncol Rep 6(1): 193-197

ROSENTHAL AN, RNAN A, AL-JEHANI RM, STOREY A, HARWOOD CA, JACOBS I (1998) p53 codon polymorphism and risk of cervical cancer in UK. Lancet 352: 871-872

ROTHHAMMER F (1987) Biological Populations History of Continental Chile. In: SCHWIDETZKY I (ed) Racial History of Mankind. Munich, Vienna: Oldenbourg Verlag. pp: 119-236

SARANATH D, KHAN Z, TANDLE AT, DEDHIA P, SHARMA B, CONTRACTOR R, SHRIVASTAVA S, DINSHAW K (2002) HPV16/18 prevalence in cervical lesions/cancers and p53 genotypes in cervical cancer patients from India. Gynecol Oncol 86(2): 157-162

STOREY A, THOMAS M, KALITA A, HARWOOD C, GARDIOL D, MANTOVANI F, BREUER J, LEIGH IM, MATLASHEWSKI G, BANKS L (1998) Role of a p53 polymorphism in the development of human papillomavirus-associated cancer. Nature 393: 229-234

SUÁREZ-RINCON AE， MORÁN-MOGUEL MC, MONTOYA-FUENTES H, GALLEGOS-ARREOLA MP, SÁNCHEZ-CORONA J (2002) Polymorphism in codon 72 of the p53 gene and cervico-uterine cancer risk in México. Ginecol Obstet Mex 70: 344-348

TACHEZY R, MIKYSKOVA I, SALAKOVA M, VAN RAST M (1999) Correlation between human papillomavirus-associated cervical cancer and p53 codon 72 arginine / proline polymorphism. Hum Genet 105: 564-566

WANG-GOHRKE S, WEIKEL W, RISCH H, VESPRINI D, ABRAHAMSON J, LERMAN C, GODWIN A, MOSLEHI R, OLIPADE O, BRUNET JS, STICKELER E, KIEBACK DG, KREIENBERG R, WEBER B, NAROD SA, RUNNEBAUM IB (1999) Intron variants of the p53 gene are associated with increased risk for ovarian cancer but not in carriers of BRCA1 or BRCA2 germline mutations. Br J Cancer 81(1): 179-183

WU WJ, KAKEHI Y, HABUCHI T, KINOSHITA H, OGAWA O, TERACHI T, HUANG CH, CHIANG CP, YOSHIDA O (1995) Allelic frequency of p53 gene codon 72 polymorphism in urologic cancers. Jpn J Cancer Res 86(8): 730-736

YU MW, YANG SY, CHIU YH, CHIANG YC, LIAW YF, CHEN CJ (1999) A p53 genetic polymorphism as a modulator of hepatocellular carcinoma risk in relation to chronic liver disease, familial tendency, and cigarette smoking in hepatitis B carriers. Hepatology 29(3): 697-702

ZUR-HAUSEN H. (2002) Papillomavirus and cancer: from basic studies to clinical applications. Nature Rev Cancer 2(5): 342-350 